\title{
THE RELATIONSHIP AMONG LEARNING INTEREST, DISCIPLINE, AND LEARNING ENVIRONMENT WITH MATHEMATICS LEARNING OUTCOMES OF EIGHTH GRADE STUDENTS OF SMP MUHAMMADIYAH BANGUNTAPAN BANTUL REGENCY OF ODD SEMESTER IN THE ACADEMIC YEAR OF 2015/2016
}

\author{
Bustanika Luthfi Harisna ${ }^{a}$, Widayatib \\ Mathematics Education Study Program, University of Ahmad Dahlan \\ Jalan Ring Road Selatan, Tamanan, Banguntapan, Bantul Yogyakarta \\ aluthfiharisna@gmail.com, bummunabilah67@gmail.com
}

\begin{abstract}
The failures of students learning are related to many factors, such as, low interest in learning something, low discipline, and less-supportive learning environment. This research intends to know the presence or absence the positive and significant correlation among learning interest, discipline and learning environment with mathematics learning outcomes of eighth-grade students of SMP Muhammadiyah Banguntapan, Bantul Regency, the first semester of the 2015/2016 academic year. The population in this research is the eighth-grade students amounting to 5 classes. The class sample was taken from the class VIII-A, and the class test was taken from the class VIII-E by random sampling technique. Data collecting technique was done by questionnaire method and testing method. The test of research instruments involves validity test, reliability test, and different power test. The test of analysis preconditions involves normality test, linearity test, and independence test. The analysis of data used product moment correlation analysis and double linear regression analysis. The result of research showed that there is a positive and significant correlation among learning interest, discipline, and learning environment with mathematics learning outcomes, as well as $\hat{Y}=-28,5840+0,2766 X_{1}+0,2412 X_{2}+0,2788 X_{3}$ and SR $X_{1}=38,181 \%, \mathrm{SR}_{2}=$ $6,593 \%$ and $\mathrm{SR} \mathrm{X}_{3}=35,226 \%$.
\end{abstract}

Keywords: Learning Interest, Discipline, Learning Environment, Learning Outcome

\section{INTRODUCTION}

Education in the life map is believed to be the most influential method in an effort to achieve the desirable order of life of society. Elements in education include study and learning. According to Fontana in Suherman, et al (2003: 7) learning is an effort to organize the environment that gives nuance so that learning programs grow and develop optimally. The purpose of learning is the realization of efficiency and effectiveness of student learning activities. One of the subjects taught at school to students is mathematics.

Mathematics is one of the subjects taught starting from Elementary School, Middle School, High School/Vocational School and Higher Education. Mathematics is a basic and compulsory subject. Mathematics learning is given to students to equip students with the ability to think logically, critically, creatively, analytically, and the ability to cooperate. There are several factors that influence learning especially learning mathematics. According to Slameto (2010: 54) factors that influence learning are classified into internal and external factors. Internal factors are factors that originate in humans, including physical and psychological factors. While external factors come from outside the individual for example the family environment, community, school. The learning outcomes of mathematics at Banguntapan SMP Muhammadiyah in Bantul Regency are very low. Evidenced from the results of the Midterm Exam in odd semester in Table 1 as follows: 
Table 1. Data of completness of Midterm exam in odd semester of Grade VIII in SMP Muhammadiyah Banguntapan in Academic Year of 2015/2016

\begin{tabular}{|l|l|l|l|}
\hline Class & Complete & Not Complete & $\begin{array}{l}\text { Number of } \\
\text { students }\end{array}$ \\
\hline VIVIII A & - & 30 & 30 \\
\hline VIVIII B & - & 30 & 30 \\
\hline VIVIII C & - & 29 & 29 \\
\hline VIVIII D & - & 32 & 32 \\
\hline VIVIII E & - & 31 & 31 \\
\hline
\end{tabular}

From the table above, there are no students who complete the minimal completeness criteria (MCC), which is 70. This is due to many factors including student learning interest in mathematics is still very lacking, students have a low level of discipline, student learning environment in students is not supportive.

One of internal factors that is thought to influence student learning is the interest in learning. In the opinion of Slameto (2010: 57) interest is a fixed tendency to pay attention and remember some activities. Activities that are of interest to someone, are constantly being watched with pleasure. So it is different from attention, because attention is temporary (not for a long time) and not necessarily followed by feeling happy, while interest is always followed by feelings of pleasure and from there satisfaction is obtained.

Internal factors that are thought to influence subsequent learning are discipline. According to Moenir (2006: 95) there are 2 types of disciplines that are very dominant in terms of producing goods or services, namely time discipline and work discipline or deeds. The task in accordance with the set time. While work discipline or reparations include: obedient and not against the rules, not lazy to learn, not telling other people to work for him, not lying, and pleasant behavior.

External factors that are thought to influence learning, one of which is the learning environment. As Mariyana, et al. (2010: 17) stated the learning environment comes from a combination of two words, environment and learning. In simple terms, the definition of a learning environment can be formulated, which is a place or atmosphere (condition) that affects the process of changing human behavior. Humans referred to here are students as subjects in that environment.

The problems in this research are is there a positive and significant relationship between interest in learning with mathematics learning outcomes, discipline and mathematics learning outcomes, the learning environment and the mathematics learning outcomes, interest in learning and discipline with the mathematics learning outcomes, interest in learning and the learning environment with students' mathematics learning outcomes, discipline and learning environment with the mathematics learning outcomes, learning interest, discipline and learning environment with the mathematics learning outcomes of students in class VIII of SMP Muhamamdiyah Banguntapan Bantul Regency in the academic year of 2015/2016.

The objectives of this research are to find out whether there is a positive or significant relationship between interest in learning and the mathematics learning outcomes, discipline and mathematics learning outcomes, learning environment and mathematics learning outcomes, interest in learning and discipline with the mathematics learning outcomes, learning interest and learning environment, discipline and learning environment with the mathematics learning outcomes, interest in learning, discipline and learning environment with the mathematics learning outcomes of eighth grade students of SMP Muhammadiyah Banguntapan Bantul Regency in the academic year of 2015/2016. 


\section{METHODS}

This research is classified as quantitative by taking place at SMP Muhammadiyah Banguntapan in the odd semester of the 2015/2016 academic year. The population in this study were all eighth grade students of the odd semester of SMP Muhammadiyah in Banguntapan consisting of 5 classes namely VIII A, VIII B, VIII C, VIIID and VIII E totaling 153 students. As a sample class taken class VIII A as many as 30 students using random sampling technique. In this study the data collection methods used were questionnaire and test methods. Questionnaire method to obtain data on learning interest, discipline and learning environment while the test method is to obtain data on student learning outcomes.

The test used is the analysis prerequisite test by the normality test of the Chi-square formula, the linearity test of the F-test formula and the test of the independence of the Chi-square formula. The research hypothesis test used a simple correlation test, multiple regression analysis and multiple linear regression tests with three independent variables. The research hypothesis test used a simple correlation test to determine whether or not there is a positive and significant relationship between: 1) interest in learning with students' mathematics learning outcomes, 2) discipline with students' mathematics learning outcomes and 3) learning environment with students' mathematics learning outcomes. Furthermore, the research hypothesis test used a multiple regression analysis test to determine whether there is a positive and significant relationship between: 1) interest in learning and discipline with students 'mathematics learning outcomes, 2) interest in learning and learning environment with students' mathematics learning outcomes, 3) discipline and the learning environment with students' mathematics learning outcomes. While the multiple linear regression test with three independent variables was conducted to determine whether or not there was a positive and significant relationship between interest in learning, discipline and the learning environment with students' mathematics learning outcomes.

\section{RESULTS AND DISCUSSION}

\section{Prerequisite Test for Regression Analysis}

\section{a. Normality test}

The summary results of the normal ability normality test can be seen in Table 2 .

Table 2. Summary of Normality Test Results

\begin{tabular}{|l|c|c|c|}
\hline Variable & $\boldsymbol{\chi}^{\mathbf{2}}$ count & $\boldsymbol{\chi}^{\mathbf{2}}$ table & df \\
\hline Interest in learning $\left(\mathrm{X}_{1}\right)$ & 5,4151 & 9,488 & 4 \\
\hline Discipline $\left(\mathrm{X}_{2}\right)$ & 2,2204 & 9,488 & 4 \\
\hline Learning environment $\left(\mathrm{X}_{3}\right)$ & 7,4512 & 7,815 & 3 \\
\hline $\begin{array}{l}\text { Mathematics learning } \\
\text { outcomes (Y) }\end{array}$ & 7,4098 & 7,815 & 3 \\
\hline
\end{tabular}

From the normality test at a significant level 5 seen $\chi^{2}$ count $\leq \chi^{2}$ table , this means that the distribution of data obtained in each variable is normally distributed.

\section{b. Linearity Test}

The summary of linearity test results can be seen in Table 3 .

Table 3. Summary of Linearity Test Results

\begin{tabular}{|l|l|l|}
\hline Variable & $\boldsymbol{F}_{\text {count }}$ & $\boldsymbol{F}_{\text {table }}$ \\
\hline $\mathrm{X}_{1}$ to $\mathrm{Y}$ & 1,1424 & 3,43 \\
\hline $\mathrm{X}_{2}$ to $\mathrm{Y}$ & 0,9293 & 3,15 \\
\hline $\mathrm{X}_{3}$ to $\mathrm{Y}$ & 0,7668 & 2,80 \\
\hline
\end{tabular}


From the normality test at a significant level $5 \% \alpha=0,05$ and the degree of freedom $v_{l}$ nominator $k$

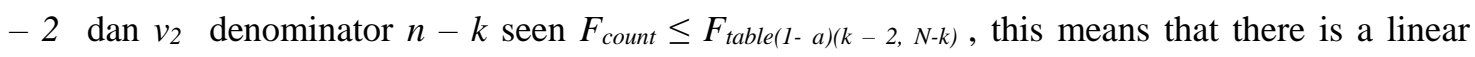
relationship between the independent variable $(\mathrm{X})$ and the dependent variable $(\mathrm{Y})$.

\section{c. Independence Test}

The summary of the results of independent tests can be seen in Table 4 .

Table 4. Summary of Independence Test Results

\begin{tabular}{|c|l|l|l|}
\hline Variable & \multicolumn{1}{|c|}{$\boldsymbol{\chi}^{\mathbf{2}}$ count } & $\boldsymbol{\chi}^{\mathbf{2}}$ table & \multicolumn{1}{c|}{ df } \\
\hline $\mathrm{X}_{1}$ and $\mathrm{X}_{2}$ & 37,100 & 37,625 & 25 \\
\hline $\mathrm{X}_{1}$ and $\mathrm{X}_{3}$ & 37,024 & 37,625 & 25 \\
\hline $\mathrm{X}_{2}$ and $\mathrm{X}_{3}$ & 31,125 & 37,625 & 25 \\
\hline
\end{tabular}

From the normality test at a significant level $5 \% \alpha=0,05$ and the degree of freedom $(d f)=(k-1)(b$ 1) seen $\chi^{2}$ count $\leq \chi^{2}$ table, this means that the distribution of data obtained on each variable is independent.

\section{Hypothesis Testing}

In the first hypothesis test obtained a simple correlation coefficient $r$ of 0.6014 at a significant level of $5 \%$. So that the $\mathrm{r}^{2}$ determinant coefficient is 0.3617 which can be explained that $36.17 \%$ of learning outcomes are influenced by interest in learning while the rest are influenced by other factors. The variation in mathematics learning outcomes $(\mathrm{Y})$ is explained by interest in learning $\left(\mathrm{X}_{1}\right)$ through a linear line $\hat{\mathrm{Y}}=$ $11.0016+0.6099 \mathrm{X}_{1}$. The results of the first hypothesis test is that there is a positive and significant relationship between interest in learning and the learning outcomes of mathematics. In other words, the higher the child's learning interest, the better the child's learning outcomes. If students have an interest in mathematics, students tend to participate and be enthusiastic when learning mathematics. In addition students will also learn well and without coercion so students who have a high interest in learning will get good learning outcomes.

In the second hypothesis test obtained the correlation coefficient (r) 0.5487 at a significant level of $5 \%$. So that obtained the determinant coefficient $\left(\mathrm{r}^{2}\right)$ of 0.3011 which can explain $30.11 \%$ of learning outcomes influenced by discipline while the rest is influenced by other factors. The variation in mathematics learning outcomes $(\mathrm{Y})$ is explained by discipline $\left(\mathrm{X}_{2}\right)$ through linear lines $\hat{\mathrm{Y}}=-17.9935+0.63357 \mathrm{X}_{2}$. The second hypothesis test results are a positive and significant relationship between discipline and mathematics learning outcomes. In other words, the higher the discipline of students, the higher the learning outcomes. If a student has a disciplined attitude, then students will certainly obey every order that applies in their school. In addition, students who have a disciplined attitude can also regulate and be responsible for their own obligations. Students who can be responsible for themselves will realize the duties and obligations that must be done as a student. Of course with discipline, students will learn well and regularly. If students learn well and regularly, students will get good learning outcomes.

In the third hypothesis test obtained the correlation coefficient (r) of 0.5572 . So that it is obtained $\left(\mathrm{r}^{2}\right)$ of 0.3105 which can explain $30.15 \%$ of learning outcomes influenced by the learning environment while the rest is influenced by other factors. The variation in mathematics learning outcomes $(\mathrm{Y})$ is explained by the learning environment $\left(\mathrm{X}_{3}\right)$ through a linear line $\hat{\mathrm{Y}}=-5.6424+0.5699 \mathrm{X}_{3}$. The third hypothesis test results are a positive and significant relationship between the learning environment and the learning outcomes of mathematics. In other words, the better the learning environment, the mathematical learning outcomes will also be good. With the supportive learning environment, students will be more excited and motivated in learning so students can learn well. So, student learning processes are closely 
related to the learning environment in which students grow and develop. A supportive learning environment will improve the mathematics learning outcomes achieved by students.

From the multiple correlation analysis, the fourth hypothesis test obtained a multiple correlation coefficient (r) of 0.6223. In this study also obtained the coefficient of determination $\left(\mathrm{r}^{2}\right)$ of 0.3873 means that $38.73 \%$ of learning outcomes are influenced by interest in learning and discipline while the rest are influenced by other factors. The variation in mathematics learning outcomes (Y) can be explained by learning interest $\left(\mathrm{X}_{1}\right)$ and discipline $\left(\mathrm{X}_{2}\right)$ through linear lines $\hat{\mathrm{Y}}=-21.7874+0.4362 \mathrm{X} 1+0.2716 \mathrm{X}_{2}$. Whereas the relative contribution of $\mathrm{X}_{1}$ is $66.788 \%$ and $\mathrm{X}_{2}$ is $33.212 \%$ and the effective contribution of $\mathrm{X}_{1}$ is $25.868 \%$ and $\mathrm{X}_{2}$ is $12.864 \%$. The fourth hypothesis test result is that there is a positive and significant relationship between interest in learning and discipline with the results of learning mathematics. In other words, the higher the students' interest in learning about mathematics, the better the child's learning outcomes. Likewise with discipline, the higher the discipline of the child, the better the learning outcomes. Students who have an interest in something will foster a sense of pleasure in it and always want to learn it. With high interest in learning student learning outcomes will increase. Likewise with discipline, discipline is also needed in the learning process because students who have a discipline attitude will foster positive attitudes and behaviors in learning and will make it easier for students to carry out learning activities and can improve mathematics learning outcomes that students will achieve.

From the multiple correlation analysis the fifth hypothesis test obtained the value of the multiple correlation coefficient $(\mathrm{R})$ of 0.6399 . In this study also obtained the coefficient of determination $\left(\mathrm{R}^{2}\right)$ of 0.4095 means that $40.95 \%$ of learning outcomes are influenced by interest in learning and the learning environment while the rest is influenced by other factors. The variation of mathematics learning outcomes (Y) can be explained by learning interest $\left(\mathrm{X}_{1}\right)$ and learning environment $\left(\mathrm{X}_{3}\right)$ through linear lines $\hat{\mathrm{Y}}=-$ $19.4826+0.4201 \mathrm{X}_{1}+0.2945 \mathrm{X}_{3}$. Whereas the relative contribution of $\mathrm{X}_{1}$ is $60.833 \%$ and $\mathrm{X}_{3}$ is $39.167 \%$ and the effective contribution of $X_{1}$ is $24.914 \%$ and $X_{3}$ is $16.041 \%$. The fifth hypothesis test results are a positive and significant relationship between interest in learning and the learning environment with the learning outcomes of mathematics. In other words, the higher the child's learning interest in mathematics, the better the child's learning outcomes. Likewise with the learning environment, the better the child's learning environment, the better the learning outcomes. Learning material that interests students, is easier to learn and digest, because of the basic interest than students learn something. Therefore, there is a great interest in learning. In addition, a home learning environment that supports the learning process will also make it easier for students to think, create, and be able to learn actively. So that there is motivation and interest in learning mathematics. With students interested in learning mathematics, the learning outcomes will be high.

From the multiple correlation analysis, the sixth hypothesis test obtained the multiple correlation coefficient $(\mathrm{R})$ of 0.6343 . In this study also obtained a coefficient of determination $\left(\mathrm{R}^{2}\right)$ of 0.4024 means that $40.24 \%$ of learning outcomes are influenced by discipline and learning environment while the rest is influenced by other factors. The variation in mathematics learning outcomes (Y) can be explained by discipline $\left(\mathrm{X}_{2}\right)$ and learning environment $\left(\mathrm{X}_{3}\right)$ through linear lines $\hat{\mathrm{Y}}=-29.2172+0.4112 \mathrm{X}_{2}+0.3811 \mathrm{X}_{3}$. Whereas the relative contribution of $\mathrm{X}_{2}$ is $48.041 \%$ and $\mathrm{X}_{3}$ is $51.599 \%$ and the effective contribution of $\mathrm{X}_{3}$ is $19.475 \%$ and $\mathrm{X}_{3}$ is $20.762 \%$. The results of the sixth hypothesis test is that there is a positive and significant relationship between discipline and the learning environment with the learning outcomes of mathematics. If students are disciplined students will obey every order and the learning process will run well so the learning outcomes will be good too. Likewise, if the home environment feels comfortable, calm, and available complete facilities and learning facilities that are needed by students in the learning process, the better learning achievement achieved. 
From the multiple correlation analysis, the seventh hypothesis test obtained the multiple correlation coefficient $(\mathrm{R})$ of 0.6554 . In this study the coefficient of determination $\left(\mathrm{R}^{2}\right)$ of 0.4296 means that $42.96 \%$ is influenced by interest in learning, discipline and learning environment while the rest is by other factors. Variations in mathematics learning outcomes $(\mathrm{Y})$ can be explained by learning interest $\left(\mathrm{X}_{1}\right)$, discipline $\left(\mathrm{X}_{2}\right)$, and learning environment $\left(\mathrm{X}_{3}\right)$ through linear lines $\hat{\mathrm{Y}}=-28.5840+0.2766 \mathrm{X}_{1}+0.2412 \mathrm{X}_{2}+0.2788 \mathrm{X}_{3}$. Whereas the relative contribution of $\mathrm{X}_{1}$ was $38.181 \%, \mathrm{X}_{2}$ was $26.593 \%$ and $\mathrm{X}_{3}$ was $35.226 \%$ and the effective contribution of $X_{1}$ was $16.403 \%, X_{2}$ was $11.424 \%$ and $X_{3}$ was $15.133 \%$. The seventh hypothesis test results are a positive and significant relationship between interest in learning, discipline and the learning environment with the learning outcomes of mathematics. In other words, the better the interest in learning, the better the learning outcomes. Likewise with discipline, the higher the discipline of the child, the higher the learning outcomes. In addition, the learning environment also influences learning outcomes, because the better and supportive the learning environment, the higher the learning outcomes.

\section{CONCLUSION}

1. There is a positive and significant relationship between interest in learning with the mathematics learning outcomes of students in class VIII of SMP Muhammadiyah Banguntapan Bantul in the academic year 2015/2016. Simple correlation coefficient (r) between interest in learning with mathematics learning outcomes of 0.6014 . And the simple regression equation $\mathrm{Y}$ for $\mathrm{X}_{1}$ is $\hat{\mathrm{Y}}=-$ $11.0016+0.6099 \mathrm{X}_{1}$.

2. There is a positive and significant relationship between discipline and the mathematics learning outcomes of students in class VIII of SMP Muhammadiyah Banguntapan Bantul in the academic year 2015/2016. Simple correlation coefficient (r) between discipline and mathematics learning outcomes of 0.5487. In addition, also obtained a simple regression equation $\mathrm{Y}$ over $\mathrm{X}_{2}$ is $\hat{\mathrm{Y}}=-17.9935+0.6357 \mathrm{X}_{2}$.

3. There is a positive and significant relationship between the learning environment and the mathematics learning outcomes of students in class VIII of SMP Muhammadiyah Banguntapan Bantul in the academic year 2015/2016. A simple correlation coefficient (r) between the learning environment and mathematics learning outcomes is 0.5572 . In addition, also obtained a simple regression equation $\mathrm{Y}$ over $\mathrm{X}_{3}$ is $\hat{\mathrm{Y}}=-5.6424+0.5699 \mathrm{X}_{3}$.

4. There is a positive and significant relationship between interest in learning and discipline with the mathematics learning outcomes of students in class VIII of SMP Muhammadiyah Banguntapan Bantul in the academic year 2015/2016. Multiple correlation coefficient (R) between interest in learning and discipline with mathematics learning outcomes of 0.6223 and coefficient of determination $\left(\mathrm{R}^{2}\right)$ of 0.3873 with linear line equations $\hat{Y}=-21.7874+0.4362 X_{1}+0.2716 X_{2}$.

5. There is a positive and significant relationship between interest in learning and the learning environment with the mathematics learning outcomes of students in class VIII of SMP Muhammadiyah Banguntapan Bantul in the academic year 2015/2016. Correlation coefficient (R) between learning interest and learning environment with mathematical learning outcomes of 0.6399 and determination coefficient $\left(R^{2}\right)$ of 0.4095 with linear line equations $\hat{Y}=-19.4826+0.4201 X_{1}+$ $0.2945 \mathrm{X}_{3}$.

6. There is a positive and significant relationship between discipline and learning environment with the mathematics learning outcomes of students in class VIII of SMP Muhammadiyah Banguntapan Bantul in the academic year 2015/2016. Correlation coefficient (R) between learning interest and learning environment with mathematics learning outcomes of 0.6343 and determination coefficient $\left(\mathrm{R}^{2}\right)$ of 0.4024 with linear line equations $\hat{Y}=-29.2172+0.4112 \mathrm{X}_{2}+0.3811 \mathrm{X}_{3}$.

7. There is a positive and significant relationship between interest in learning, discipline and learning environment with the mathematics learning outcomes of students in class VIII of SMP 
Muhammadiyah Banguntapan Bantul in the academic year 2015/2016. Correlation coefficient (R) between interest in learning, discipline and learning environment with mathematical learning outcomes of 0.6554 and coefficient of determination $\left(R^{2}\right)$ of 0.4296 with linear line equations $\hat{Y}=-28.5840+$ $0.2766 \mathrm{X}_{1}+0.2412 \mathrm{X}_{2}+0.2788 \mathrm{X}_{3}$.

\section{REFERENCES}

Mariyana, dkk. 2010. Pengelolaan Lingkungan Belajar. Jakarta : Kencana.

Moenir. 2006. Manajemen Pelayanan Umum di Indonesia. Jakarta : Bumi Aksara.

Slameto. 2010. Belajar dan Faktor - Faktor yang Mempengaruhi. Jakarta : Rineka Cipta.

Suherman, dkk. 2003. Strategi Pembelajaran Matematika Kontemporer. Bandung : Universitas Pendidikan Indonesia. 